\title{
Strange as it may seem: the many links between Wnt signaling, planar cell polarity, and cilia
}

\author{
John B. Wallingford ${ }^{1,3}$ and Brian Mitchell ${ }^{2}$ \\ ${ }^{1}$ Howard Hughes Medical Institute, Section of Molecular Cell and Developmental Biology, Institute for Cellular and Molecular \\ Biology, University of Texas, Austin, Texas 78712, USA; ${ }^{2}$ Department of Cell and Molecular Biology, Feinberg School of \\ Medicine, Northwestern University, Chicago, Illinois 60611, USA
}

\begin{abstract}
Cilia are important cellular structures that have been implicated in a variety of signaling cascades. In this review, we discuss the current evidence for and against a link between cilia and both the canonical Wnt/B-catenin pathway and the noncanonical Wnt/planar cell polarity (PCP) pathway. Furthermore, we address the evidence implicating a role for PCP components in ciliogenesis. Given the lack of consensus in the field, we use new data on the control of ciliary protein localization as a basis for proposing new models by which cell type-specific regulation of ciliary components via differential transport, regulated entry and exit, or diffusion barriers might generate context-dependent functions for cilia.
\end{abstract}

It has been asserted that cilia were the first cellular organelles to be described, when Leeuwenhoek himself (as translated in Dobell 1958) observed single cells propelling themselves with tiny cellular projections (see Satir 1995). Roughly 300 years later, nonmotile primary cilia were first described, and among the earliest functions ascribed to them were sensory. That these assertions proved to be correct is among the more striking recent breakthroughs in developmental biology. Indeed, forward genetic screens in the mouse revealed that cilia play a crucial role in the regulation of the Hedgehog signaling pathway in vertebrates (Huangfu et al. 2003; Eggenschwiler and Anderson 2007; Goetz and Anderson 2010).

Following quickly on these findings, a large class of human diseases and syndromes (the "ciliopathies") have emerged that display overlapping phenotypic spectra and are linked by a shared etiology involving mutations in genes associated with ciliogenesis or cilia function (for review, see Baker and Beales 2009). Strikingly, however, not all ciliopathy phenotypes can be readily explained by

[Keywords: cilia; Wnt signaling; planar cell polarity; basal bodies; diffusion barriers; ciliary pores; IFT]

${ }^{3}$ Corresponding author.

E-MAIL wallingford@mail.utexas.edu; FAX (512) 471-3878.

Article is online at http://www.genesdev.org/cgi/doi/10.1101/gad.2008011.

Freely available online through the Genes \& Development Open Access option. alterations of Hh signaling, leading to the hypothesis that primary cilia might act more generally as cellular antennae for a variety of cell signaling events, including PDGF signaling, sensory taste signaling, and Wnt signaling (Schneider et al. 2005; Simons et al. 2005; Shah et al. 2009). A general role for cilia in signaling is appealing given the recent string of studies showing that entry into the cilium is a tightly regulated process. Modulating ciliary localization of signal transducers could be a mechanism for "tuning" cilia to be more or less sensitive to a given signal.

The results supporting an essential role for cilia or ciliaassociated proteins in vertebrate Hh signaling are extensive, and a consensus view is beginning to take shape (Eggenschwiler and Anderson 2007; Goetz and Anderson 2010). In stark contrast, the role for cilia in Wnt signaling remains much more elusive. Indeed, the very issue of what, if any, links exist between cilia and the Wnt $/ \beta$-catenin or Wnt/PCP (planar cell polarity) pathways remains quite contentious. The multitude of reported links are the topic of the present review, but the reader should be forewarned. Solid conclusions will be scarce. Perhaps this is fitting: Sharpey (1836) wrote of his own review on cilia in 1836 that "considerable space has been allotted to the present article, more perhaps than its relative importance may seem to demand." Some 30 pages later, he expressed dismay that, "strange as it may seem, after what has been said, some observers maintain that the cilia have no real existence... that the whole is an optical illusion" (Sharpey 1836). Likewise, while there is compelling evidence for roles for cilia in Wnt and PCP signaling, there is also compelling evidence to the contrary.

Here, we address these many studies, starting with canonical Wnt $/ \beta$-catenin signaling. We then proceed to studies linking cilia to PCP signaling and studies that conversely demonstrate a role for certain PCP proteins in the initial assembly of cilia. Finally, we discuss recent advances in our understanding of how cells regulate which proteins get into and out of their cilia, thus providing new mechanisms by which cilia may be used by cells to generate context-dependent responses to extracellular signaling, including, perhaps, Wnts. 


\section{Cilia and canonical Wnt signaling}

Canonical Wnt signaling is implicated in a large number of developmental and disease processes. Put simplistically, a secreted Wnt ligand binds to and activates the Frizzled class of receptors, leading to stabilization and nuclear localization of $\beta$-catenin and subsequent activation of Wnt target genes (for review, see van Amerongen and Nusse 2009). In reality, this pathway is significantly more complex, as is evident from the multiple feedback mechanisms at work and the delicate balance of a large number of regulatory components during Wnt signaling (for example, see Lee et al. 2003). One can see how receptor localization and regulatory confinement to the cilia might offer significant advantages in terms of concentrating and regulating signaling efforts. Indeed, a number of Wnt signaling components have been observed in cilia and at basal bodies.

One of the first connections between cilia and the canonical Wnt pathway came from evidence that the inversin gene product Nephrocystin2 (also called Inv) localized to cilia and physically interacted with the core Wnt pathway component, Dishevelled (Dvl) (Otto et al. 2003; Watanabe et al. 2003; Simons et al. 2005). Cotransfection experiments showed that Inv abrogated the ability of Dvl to drive activation of a Wnt-responsive reporter construct (Simons et al. 2005). Thus, the early indications suggested that canonical Wnt signaling was actually constrained rather than potentiated by events at primary cilia.

The first direct look at the link between cilia and Wnt signaling arose from the observation that knockdown of any of several genes associated with the well-defined ciliopathy Bardet-Biedl syndrome (BBS1, BB4, and $M K K S)$ resulted in a hyperactive Wnt response in cultured cells (Gerdes et al. 2007). Likewise, knockdown of Kif3a, the kinesin motor essential for ciliogenesis, also resulted in severalfold up-regulation of the cells' response to exogenously supplied Wnt3a (Gerdes et al. 2007). These studies were followed shortly by another report showing that disruption of primary cilia in mice harboring mutations in kif3a, Ift88, or of $d 1$ also resulted in a marked increase in cellular responses to canonical Wnt pathway activation (Corbit et al. 2008). Moreover, the presence of a primary cilium significantly constrained canonical Wnt signaling in both cultured mouse embryo fibroblasts (MEFs) and embryonic stem cells (Corbit et al. 2008). Subsequent studies have reached similar conclusions, as is outlined below.

It is important, however, to note that some recent studies argue there is in fact no role at all for cilia in Wnt signaling. For example, maternal/zygotic zebrafish mutant in the ift88 gene fail to make cilia, but, while these mutants do display the expected Hh-related phenotypes, they showed no apparent defects in Wnt-dependent developmental processes or in expression of known Wnt target genes (Huang and Schier 2009). Likewise, another analysis found that the Wnt target gene Axin2 and a transgenic Wnt reporter were both normal in mouse embryos lacking ift88, ift72, or kif3a (Ocbina et al. 2009). Moreover, this study also examined MEFs generated from wild-type and cilia-defective mice using a quantitative
Wnt reporter and found no difference in the response to Wnt ligand (Ocbina et al. 2009).

Despite these important dissenting views, several other reports support a role for cilia (or cilia-associated proteins) in restraining Wnt signaling. For example, loss of primary cilia in mammary ducts of Ift 88 mutant mice resulted in both an increase in Wnt signaling and a decrease in $\mathrm{Hh}$ signaling (McDermott et al. 2010). Likewise, Chibby, a basal body-associated protein, is required for ciliogenesis in the airway and can also bind $\beta$-catenin and negatively regulate Wnt signaling (Takemaru et al. 2003; Voronina et al. 2009). In both the airway and in MEFs, mutation of chibby results in up-regulated Wnt responses (Voronina et al. 2009).

Evidence indicating a role for cilia in negative regulation of Wnt $/ \beta$-catenin activity is not restricted to the mouse. The zebrafish seahorse gene was identified in a screen for genes affecting kidney cyst formation, a common phenotype of ciliopathies. While Seahorse protein does not localize to cilia, the seahorse gene is highly expressed in ciliated tissues, suggesting that it is involved in cilia function (Kishimoto et al. 2008). Interestingly, Seahorse binds to Dvl, and seahorse morphants have a phenotype consistent with an expansion of Wnt signaling, suggesting that Seahorse somehow constrains Wnt signaling in zebrafish. Likewise, overexpression of the lipogenic transcription factor (SREBP1C) disrupts ciliogenesis and elevates Wnt/ $\beta$-catenin signaling in Xenopus (Willemarck et al. 2010).

Finally, the complexity of this issue is perhaps most sharply rendered by a return to where it all started: the kidney. Cilia defects are linked tightly to cystic kidney disease, and experiments with NPHP2/Inv first implicated a cilia-associated protein with Wnt signaling (Simons et al. 2005). More recent data have been somewhat confounding. On the one hand, loss of cilia in the kidney of Ift 20 mutant mice was associated with an increase in nuclear, dephosphorylated $\beta$-catenin and increase in expression of a variety of Wnt target genes (Jonassen et al. 2008). In contrast, mice mutant for the Joubert syndrome gene Ahi1/Jbn show abrogated canonical Wnt signaling in the kidney (Lancaster et al. 2009). While Jbn seems to control Wnt signaling by facilitating nuclear entry of $\beta$-catenin (Lancaster et al. 2009), its relationship with cilia is unclear. One group (Lancaster et al. 2009) reported that Jbn is not required for ciliogenesis, but another group (Hsiao et al. 2009) reported that it is required. Both groups reported a role for Jbn in trafficking in the photoreceptor connecting cilium (Louie et al. 2010; Westfall et al. 2010). Taken together, these results might seem to indicate a positive, rather than negative, role for Jbn and cilia in Wnt signaling. An alternative explanation is that Jbn is sequestered at cilia in order to restrain Wnt signaling, such that disruption of cilia (by mutation of IFT [intraflagellar transport] genes, for example) would release Jbn and allow it to potentiate $\beta$-catenin entry to the nucleus and thus stimulate Wnt signaling. Complicating this view, however, is the fact that another basal body-localized protein, Chibby, does just the opposite-inhibiting Wnt signaling by preventing nuclear entry of $\beta$-catenin $(\mathrm{Li}$ et al. 2008). We discuss direct connections between 
nuclear import machinery and cilia in much more detail below.

In summary, several lines of evidence support the idea that cilia or cilia-associated proteins can act to constrain canonical Wnt $/ \beta$-catenin signaling. Nonetheless, the overall embryonic phenotypes of mice with mutations in core ciliogenesis genes (Ift88, etc.) do not display overt and widespread defects in Wnt-mediated developmental processes, although these mice do overtly resemble mice with defective Hh signaling. What, then, are we to conclude? It would seem that the role of cilia in the canonical Wnt pathway-whatever it is-is both cell type-specific and also significantly more subtle than is the role of cilia in Hh signaling. Given the already bedeviling complexity of the role of cilia in Hh signal transduction, it seems that one safe conclusion is that working out the details of the cilium's partnership with canonical Wnt signaling will provide for some exciting new avenues of research. Indeed, clinical significance for this issue may be expanding beyond the well-known ciliopathies, as a potential link between Wnt signaling and cilia has been noted in medulloblastoma (Han et al. 2009).

\section{Cilia and PCP signaling}

The ability of cells to orient relative to an axis along the plane of the tissue is called PCP, and in many tissues this property is controlled by a noncanonical branch of the Wnt pathway: the PCP cascade. This pathway was originally delineated in Drosophila, and is centered on the planar-polarized accumulation of various components to distinct regions of the cell. The core components of the pathway include the transmembrane proteins Frizzled, Van Gogh, and Flamingo (vertebrate Fz, Vangl, and Celsr, respectively), and the cytoplasmic proteins Prickle and Dvl (for review, see Vladar et al. 2009; McNeill 2010).

The first demonstration of its role in vertebrates came from studies of the collective cell movement called convergent extension (CE) (Sokol 1996; Heisenberg et al. 2000; Tada and Smith 2000; Wallingford et al. 2000). This process is driven by the polarized interdigitation of cells specifically along the mediolateral axis of the embryo (Shih and Keller 1992; Keller 2002); failure of CE results in defective neural tube closure in both Xenopus and mice (Wallingford and Harland 2002; J Wang et al. 2006; Y Wang et al. 2006; Ybot-Gonzalez et al. 2007). PCP signaling was subsequently shown to govern a variety of planar-polarized cell behaviors in vertebrates, including the orientation of stereocilia in the cochlea and of hair follicles in the epidermis (Montcouquiol et al. 2003; Guo et al. 2004; Devenport and Fuchs 2008; Jones et al. 2008).

Quite recently, PCP signaling was found to be required for polarized beating of motile cilia in a variety of tissues. Work in multiciliated cells of the Xenopus epidermis revealed that Dvl and Vangl2 control the planar orientation of basal bodies, which in turn controls directional ciliary beating (Park et al. 2008; Mitchell et al. 2009). Subsequent studies showed that these and other PCP proteins also control the directed beating of multiciliated ependymal cells of the mouse brain and the zebrafish kidney (Borovina et al. 2010; Guirao et al. 2010; Tissir et al. 2010). Finally, PCP signaling is also required for leftright patterning, owing to its role in the planar positioning of motile monocilia in the node of mice, the gastrocoel roof of Xenopus, and the Kupffer's vesicle of zebrafish (Antic et al. 2010; Borovina et al. 2010; Hashimoto et al. 2010; Song et al. 2010). The role of PCP in directed cilia beating is the subject of a recent review (Wallingford 2010), and is not elaborated on further here.

A number of other studies have posited a role for cilia in PCP signaling, and this area remains quite murky. As mentioned above, Inv interacts with Dvl, which is involved in both canonical and noncanonical Wnt signaling (Simons et al. 2005). Inv also bears striking homology with the Drosophila PCP gene Diego (Feiguin et al. 2001), and loss of Inv results in CE defects, consistent with a role for Inv/NPHP2 in vertebrate PCP (Simons et al. 2005). These results led Simons et al. (2005) to propose that Inv/ NPHP2 at the base of primary cilia may act as a molecular switch, somehow regulating the balance between canonical Wnt signaling and Wnt/PCP signaling.

Further evidence suggesting a link between cilia and PCP signaling has come from examination of phenotypes in mice mutant for genes associated with the ciliopathy BBS (Ross et al. 2005). The loss of BBS1, BBS4, or Mkks (BBS6) resulted in mice with open eyelids and disorganized stereocilia in the cochlea, features common in PCP mutant mice (Ross et al. 2005). Additionally, several ciliopathy genes interact genetically with the PCP component Vang12, resulting in more severe cochlear orientation defects and CE defects (Ross et al. 2005; Gerdes et al. 2007; Jones et al. 2008; Leitch et al. 2008; MaySimera et al. 2010). Indeed, tagged versions of BBS8 and Vangl2 can be coimmunoprecipitated when coexpressed in cultured cells (May-Simera et al. 2010). Finally, manipulations of another ciliopathy gene, ofd1, also elicits CE defects in zebrafish and also displays functional synergy with Vangl2, indicating a genetic interaction between Ofd1 and the PCP pathway (Ferrante et al. 2009).

Together, these data would seem to argue for a role for cilia or cilia-related proteins in PCP signaling. However, maternal/zygotic mutation of Ift88 in zebrafish did not result in defective CE (Huang and Schier 2009). Moreover, we would argue that some notes of caution are needed in interpreting the results of the many experiments linking PCP signaling to cilia. First, many of the genetic interactions have been based on the rates of neural tube defects (NTDs) in mutant mice. However, neural tube closure in mammals is a complex trait, and genes involved in closure in one region of the neural tube are not necessarily involved in other regions (Wallingford 2006; Murdoch and Copp 2010). To wit: The specific class of NTDs consistently found in PCP mutant mice is called craniorachischisis and affects the entirety of the hindbrain and spinal cord. This NTD is noteworthy because it involves a failure of the initial closure point of the vertebrate neural tube at the level of the hindbrain, and is consistently observed in the core PCP mutant mice, including Dvl, Frizzled, Vangl2, and Celsr1 (Kibar et al. 2001; Hamblet et al. 2002; Curtin et al. 2003; Y Wang 
et al. 2006). This NTD is a consequence of defects in CE cell movements (Wallingford and Harland 2002; J Wang et al. 2006; Ybot-Gonzalez et al. 2007).

Strikingly however, mutations that dramatically impair ciliogenesis do not result in craniorachischisis; the initial closure in the hindbrain is normal (Huangfu et al. 2003; Huangfu and Anderson 2005; Liu et al. 2005; Caspary et al. 2007). Rather, cilia mutant mice display an NTD called exencephaly, in which the forebrain remains open (see a detailed discussion of this point in Murdoch and Copp 2010). Mice with mutations in core PCP genes very rarely display exencephaly. Given the large number of region-autonomous morphogenetic processes that collaborate to close the vertebrate neural tube (Colas and Schoenwolf 2001; Copp et al. 2003; Wallingford 2006), it may be that the genetic interactions observed between PCP genes and ciliary genes in mice have more to do with the physical integration of different morphogenetic processes in the forming neural tube than with integration of specific molecular signals. In addition, the emerging roles for at least some PCP proteins in the process of ciliogenesis (see below) may further confound interpretation of the results of genetic crosses.

Finally, and perhaps most significantly, while the mechanistic basis of the cilium's role in Hh signaling is emerging, there is not an obvious way to link a role for cilia into the current mechanistic frameworks for PCP signaling. This contention stems from the "geometric" nature of the PCP signaling readout, as compared with other signaling pathways. Signaling systems such as the canonical Wnt or Hh pathways act at the level of transcription, with biochemical changes in transduction components leading to changes in the access of transcription factors to the target DNA. The PCP pathway, in contrast, controls cell morphology, rather than transcription, and thus there is no specific biochemical metric for "activation" of the PCP signaling cascade. Instead, in tissues where it is best understood (Drosophila wing and vertebrate cochlea), it is the asymmetric and mutually antagonistic spatial localization of core PCP proteins that serve as the key readout for this pathway's activity (for review, see Strutt 2002; Vladar et al. 2009; McNeill 2010). These asymmetric complexes then interface with fundamental cellular machinery (cytoskeleton, etc.) to affect a polarized cellular morphology.

This view of PCP signaling thus distinguishes between "active PCP signaling" (based on asymmetric localization of PCP components) and a cell's ability to execute a polarized cellular or subcellular behavior. The two can be quite separable. An excellent example is provided by a fascinating study of the mouse vestibular system, which displays planar-polarized positioning of hair cells similar to those commonly studied in the cochlea. Kinocilia are positioned on opposite sides of cells in various regions of the vestibular epithelium; some are positioned medially, and others laterally. Strikingly, although kinocilium positions are reversed, the asymmetric positioning of the core PCP proteins Prickle2 and Frizzled6 is not reversed, and stays consistent across the entire tissue (Deans et al. 2007). As such, a unifying model involving a direct and functional link between the cilium and asymmetric accumulation of core PCP proteins is at present difficult to envision. In the following section, we discuss an alternative model that might explain the link between cilia-associated proteins and cell polarity.

\section{Cilia and PCP signaling versus cilia and PCP}

Moving forward, a critical distinction must be made between PCP signaling and planar polarization of cells. While the PCP signaling cascade has received much attention, some epithelia clearly can achieve planar polarization in the absence of this one signaling pathway. For example, mediolateral cell intercalations and planarpolarized cell divisions that drive germband elongation in Drosophila do not require PCP signaling (Zallen and Wieschaus 2004; da Silva and Vincent 2007). Thus, one intriguing idea is that cilia-associated proteins are involved in generating planar polarity, but that they do so in a way that is independent from the noncanonical Wnt/ PCP signaling pathway.

The best evidence for this so far comes from the inner ear, where conditional mutation of Ift 88 , which is critical in the cochlea for formation of the kinocilium but not for actin-based stereocilia, resulted in a disorganization of the planar-polarized orientation of those stereocilia (Jones et al. 2008). Interestingly, even though these cells appeared morphologically unpolarized, they maintained proper asymmetric localization of core PCP components, suggesting that the loss of cilia was acting to control polarized cell behavior independently of or downstream from the PCP signaling apparatus (Jones et al. 2008). A similar situation was subsequently described in the multiciliated mouse ependymal cells, where mutation of Ift88 leads to a defect in planar polarization of directed ciliary beating but does not disrupt the planar-polarized distribution of Vangl2 protein (Guirao et al. 2010).

These ependymal cells also offer a second example of the important distinction between PCP signaling specifically and planar cell polarization generally. The planar orientation of basal bodies is governed by PCP signaling (see Wallingford 2010), but ependymal cells also display an additional form of planar polarization manifested by the asymmetric clustering of cilia on the apical cell surface (Mirzadeh et al. 2010). An elegant set of experiments showed that if ciliogenesis is disrupted in the precursors of these ependymal cells (radial glial cells), then the polarized clustering of ependymal cilia was disrupted, indicating that cilia are somehow involved in the generation of this element of ependymal cell planar polarity (Mirzadeh et al. 2010). Notably, however, this planarpolarized clustering of cilia does not require PCP signaling (Hirota et al. 2010).

These data suggest a model in which cilia (or ciliaassociated proteins) can influence planar cell polarization independently of the PCP signaling machinery. How might they do this? One intriguing possibility focuses on the centrosome. Polarized cell migration in vitro has long been associated with planar-polarized positioning of the centrosome (e.g., Kupfer et al. 1982; Gomes et al. 
2005). Indeed, manipulation of certain PCP signaling components can disrupt the migration of cultured cells and correspondingly randomizes centrosome positioning (Schlessinger et al. 2007).

When considering cell migration and planar polarity, it is tempting (and often intellectually useful) to ignore the third dimension. However, PCP-mediated collective cell movements such as CE involve moving cells that are oriented in all three dimensions. These "hexahedral" cells engage in behaviors that are polarized along both the mediolateral (planar) axis and also the orthogonal, deep/ superficial axis (see the discussion in Green and Davidson 2007). It may be that centrosome position is an essential facet of cells' ability to sense polarizing information and act on it in order to execute the necessary polarized behaviors in three dimensions.

There is accumulating evidence that this is in fact the case. In Xenopus, microtubule growth is polarized in both mediolateral and deep/superficial axes. Growing microtubules are present mainly in the deep cytoplasm, and growth is preferentially oriented laterally (Shindo et al. 2008). Likewise, in zebrafish, centrosomes display polarized localization near the nascent apical surfaces of epithelializing mesoderm and ectoderm cells during gastrulation; their position is also planar-polarized, with a posterior bias early and a medial bias late in gastrulation (D Sepich and L Solnica-Krezel, pers comm.).

If centrosome position is ultimately central to polarized cell movements, then it seems possible that the genetic interactions between PCP proteins and ciliaassociated proteins may be telling us less about molecular cross-talk than about the interdependence of two distinct elements of the cells' polarizing machinery. Consistent with this notion is the fact that many proteins that play roles in ciliogenesis also play a role in establishing or maintaining centrosome position (e.g., Ift20) (Jonassen et al. 2008). Moreover, several of the very same proteins that display robust genetic interactions with PCP genes during $\mathrm{CE}$ are also known to play a role at the centrosome. For example, OFD1 is essential for centrosomal structure (Singla et al. 2010) and BBS4 is necessary for anchoring of microtubules to the centrosome (Kim et al. 2010). Finally, recent work has demonstrated that Daam1, an effector of Dvl-mediated PCP signaling (Habas et al. 2001 ), is also required for centrosome positioning in migrating cultured cells (Ang et al. 2010).

So, it is clear that cilia and/or cilia-associated proteins can, in certain contexts, influence planar cell polarization, even if their role in PCP signaling per se remains unclear. As if this connection was not confusing enough already, there is now substantial evidence that at least some PCP signaling proteins are important for ciliogenesis.

\section{'PCP effector' proteins and ciliogenesis}

The first direct evidence for a link between PCP signaling and the assembly of cilia came from analysis of the littlestudied "PCP effector" proteins Inturned and Fuzzy, which are essential for PCP signaling in Drosophila wings (Park et al. 1996; Lee and Adler 2002; Adler et al. 2004;
Collier et al. 2005). In Xenopus, these are highly expressed in ciliated tissues, and MO-mediated knockdown results in profound defects in ciliogenesis and Hedgehog signaling (Park et al. 2006). The requirement for these proteins in ciliogenesis and $\mathrm{Hh}$ signaling is conserved in the mouse (Gray et al. 2009; Heydeck et al. 2009; Dai et al. 2010; Zeng et al. 2010).

Inturned encodes a novel PDZ-containing protein that functions downstream from core PCP proteins to control the planar polarization of hairs and bristles in Drosophila (Park et al. 1996; Lee and Adler 2002). In Drosophila, Inturned is a cytoplasmic protein that localizes near the plasma membrane on the proximal side of wing epithelial cells (Yun et al. 1999; Adler et al. 2004), in the vicinity of the core PCP proteins Prickle and Van Gogh (Tree et al. 2002; Bastock et al. 2003). Indeed, Van Gogh is required for Inturned localization (Adler et al. 2004). In vertebrates, Inturned localizes diffusely in the cytoplasm of cells with a single primary cilium and is diffusely localized, but apically enriched, in multiciliated epithelial cells (Park et al. 2006; Zeng et al. 2010). Notably, a GFP fusion to Inturned that is likewise diffusely localized can rescue ciliogenesis in Inturned-null fibroblasts (Zeng et al. 2010).

Knockdown in Xenopus has shown that Inturned is required for actin assembly, Rho localization, and docking of basal bodies at the apical surface in multiciliated cells (Park et al. 2008). These results dovetail nicely with the findings that Rho-mediated actin assembly is required for apical docking of basal bodies in mammalian airway and quail oviduct (Boisvieux-Ulrich et al. 1990; Huang et al. 2003; Pan et al. 2007). Likewise, in Drosophila, Inturned binds to the formin-like actin regulator Multiple Wing Hairs (MWH) (Strutt and Warrington 2008). While there is no obvious vertebrate ortholog of $\mathrm{MWH}$, these data may provide a measure of mechanistic insight, given the key role for Rho GTPases and the formin protein Daam1 in PCP-mediated CE (Habas et al. 2001, 2003; Marlow et al. 2002; Ybot-Gonzalez et al. 2007).

Fuzzy also encodes a novel protein, and little is known of the function of the Fuzzy protein in Drosophila (Collier and Gubb 1997; Lee and Adler 2002). For vertebrate Fuzzy, a variety of computational analyses predict that it serves a vesicle trafficking function (Gray et al. 2009). Unlike Inturned, Fuzzy is not essential for basal body docking, but rather is required for axoneme elongation. Fuzzy acts together with a Rab-similar GTPase (RSG1) to govern trafficking from the cytoplasm to basal bodies and from the basal body to the tips of cilia (Gray et al. 2009). How Fuzzy relates to other cilia trafficking systems such as the BBSome and IFT remain a key open question, but it is quite curious that both Fuzzy and Ift20 have been implicated as playing roles in exocytosis that are independent of their roles in ciliogenesis (Finetti et al. 2009; Gray et al. 2009).

An important question remains. While Inturned and Fuzzy play clear roles in planar polarization of wing hairs in Drosophila (Lee and Adler 2002), it is not clear that they control developmental processes generally associated with PCP in vertebrates, such as CE. Knockdown of 
either gene leads to mild CE defects in Xenopus, but mutant mice do not display the craniorachischisis phenotype associated with mutation of core PCP genes (Park et al. 2006; Gray et al. 2009; Heydeck et al. 2009; Zeng et al. 2010). Moreover, while widespread Hh-related defects have been observed in the epidermis of Fuz mutant mice, no defects were seen in the planar polarization of hair follicles (Dai et al. 2010), as may be expected from mutation of a critical PCP gene (e.g., Guo et al. 2004; Devenport and Fuchs 2008).

Thus, the role for genes designated as "PCP effectors" in Drosophila remains unclear with respect to vertebrate PCP signaling. Adding to the confusion is the recent report on the vertebrate ortholog of another relatively obscure Drosophila PCP protein. The cytoplasmic WD40 repeat protein Fritz is essential for PCP in Drosophila wings, and is counted among the PCP effectors (Collier et al. 2005). The Xenopus ortholog of Fritz is expressed in ciliated cells, and knockdown results in defects in ciliogenesis and Hh signaling (Kim et al. 2010). However, knockdown also leads to substantial defects in CE. Fritz interacts physically with septins and appears to act via septins during both ciliogenesis and CE. Finally, mutations in human Fritz (C2orf86) were found to be associated with two ciliopathies: Meckel-Gruber syndrome and BBS (Kim et al. 2010).

\section{Core PCP proteins and ciliogenesis}

While the role for the so-called PCP effector proteins in ciliogenesis is now well established, the role of core PCP proteins in ciliogenesis is rather more nettlesome. The first evidence for such a function came from zebrafish, where the Cap-Zip actin regulator Duboraya was shown to mediate PCP signaling and govern ciliogenesis (Oishi et al. 2006). Oishi et al. (2006) went on to show that manipulations of either Frizzled or Dvl resulted in defective ciliogenesis in Kupffer's vesicle.

Subsequently, Dvl was shown to govern ciliogenesis in multiciliated cells of the Xenopus epidermis. As for Inturned, Dvl was found to be essential for apical actin assembly, Rho activity, and basal body docking (Park et al. 2008). Notably, Duboraya is also required for apical actin assembly in ciliated cells (Oishi et al. 2006). Basal body docking involves the association of nascent basal bodies with membrane-bound vesicles, and recent results implicate the vesicle tethering exocyst complex in ciliogenesis (Sorokin 1968; Rogers et al. 2004; Zuo et al. 2009). Dvl appears to control basal body docking at this level, as basal bodies failed to associate with either vesicles or the exocyst in Dvl morphants (Park et al. 2008).

An additional tentative link between Dvl and ciliogenesis comes from human genetic studies. The tetraspan transmembrane protein TMEM216 was found to be mutated in cases of both Meckels syndrome (MKS) and Joubert syndrome-related disorders (JSRD) (Valente et al. 2010). TMEM216 localizes to basal bodies and centrosomes, and knockdown results in defects in basal body docking and ciliogenesis. TMEM216 interacts physically with another MKS protein, Meckelin (TMEM67), and knockdown of either results in hyperactivation of RhoA and phosphorylation of Dvl (Valente et al. 2010).

While the situation with Dvl remains to be further investigated, a recent study does clearly demonstrate a requirement for another core PCP protein in ciliogenesis. Mice with mutations in genes orthologous to Drosophila Starry Night/Flamingo (Celsr2 and Celsr3) display severe defects in ciliogenesis in the multiciliated ependymal cells of the brain (Tissir et al. 2010). In mice lacking Celsr2 and Celsr3, ependymal cells differentiate normally, but form few or no cilia. As was the case for Dvl in Xenopus, the cilia defects in Celsr mutant mice were shown to stem from a failure of basal body docking at the apical plasma membrane. Indeed, in some cases, intracellular cilia were seen extending from basal bodies still located deep inside the cytoplasm of Celsr mutant ependymal cells (Tissir et al. 2010). Finally, recent data support a potential role for Prickle in regulating cilium length (Oteiza et al. 2010).

While it appears that some core PCP proteins do play a role in ciliogenesis, at least in certain cell types, the issue of the "PCP pathway" being required for ciliogenesis becomes uncertain when manipulations of Vangl proteins are considered. Vangl2 has been reported to localize to cilia in some systems (Ross et al. 2005; Guirao et al. 2010) but not in others (Song et al. 2010). In Xenopus, MO-mediated knockdown of Vangl2 in epidermal multiciliated cells results in disruption of basal body localization and ciliogenesis (Mitchell et al. 2009). It should be noted that Vangl2 MO does not completely eliminate cilia but reduces the number of basal bodies that apically dock and template cilia. Curiously, assembly of nodal monocilia is unaffected by Vangl2 knockdown (Antic et al. 2010). In mice, mutation of Vangll and Vangl2 did not elicit ciliogenesis defects in either multiciliated airway cells, the neural tube, or cultured MEFs (Song et al. 2010). Adding to the confusion, conflicting reports have come from zebrafish studies. One study has reported that Vangl2 mutant embryos display no defects in ciliogenesis in Kupffer's vesicle cells, multiciliated cells of the pronephros, or mono-ciliated floorplate cells of the early neural tube (Borovina et al. 2010). In contrast, another study reports that these same mutant fish display reduced numbers of KV cilia, and, moreover, that basal bodies appear to be not properly positioned apically (MaySimera et al. 2010). Certainly, this issue warrants more detailed quantitative analyses.

The role of core PCP proteins in ciliogenesis remains, therefore, rather confusing, although there is a plausible explanation that actually ties together some disparate findings in the field. Clearly, the asymmetric localization of core PCP components is widely discussed (Adler 2002; Strutt 2002), but what is less well known is that these PCP proteins must first be positioned apically (e.g., Das et al. 2004; Wu et al. 2004). As it happens, the apicobasal polarity protein Scribble interacts functionally and physically with PCP components in both flies and mice (Montcouquiol et al. 2003; Murdoch et al. 2003; Courbard et al. 2009). One could speculate, then, that the machinery driving this initial apical localization of PCP components 
might also be used by the cell to mediate the apical localization of basal bodies. Whether this represents a novel aspect of the PCP pathway in general or is the result of individual PCP proteins having multiple cellular functions remains to be determined.

\section{All cilia are not the same}

The ciliopathies are represented by an ever-growing catalog of diseases all linked by mutation of genes associated with cilia structure or function. Interesting, and perhaps somewhat telling, is the fact that these conditions are characterized by a surprisingly wide range of phenotypes that are only partially overlapping. In patients with a complete loss of cilia, the overwhelming phenotypes are associated with Hh signaling. However, many ciliopathies involve genetic mutations that only mildly effect ciliary structure and are more likely to effect specific aspects of ciliary function. There are several potentially non-Hh-related phenotypes that characterize the ciliopathies (cystic kidneys, for example), and the wide variety of milder defects suggest tissue or cell type specificity. These findings may reflect the important fact that all cilia are not created equal (Fig. 1), and that there may be many developmentally regulated and/or contextdependent ciliary functions that have yet to be discovered. If this is true, how is it that ciliary diversity is controlled and maintained? How does such diversity relate to disease presentation? A number of recent studies have begun to address these questions from very different directions. In the remainder of this review, we discuss some of these new findings in ciliary biology and how they may (or may not) relate to Wnt signaling and PCP.

\section{Basal bodies as ciliary docking stations}

Centrioles are the primary microtubule-organizing centers of the cell. This is elegantly displayed when they serve as the nucleating point of aster formation during mitosis. Due to the importance of centrioles for various cellular functions, they have evolved as important centers for protein-protein interactions, particularly during the cell cycle (Marshall 2007; Nigg 2007). One of the more intriguing advances in the field of ciliary signaling is the idea that basal bodies (i.e., centrioles) are more then simply the nucleating site of cilia, but that they also serve as a docking station for proteins in transit to the cilium. This point is highlighted by the fact that many mutations that lead to ciliopathies are in genes that encode proteins that localize to basal bodies rather than to cilia. Since many of the proteins that make it to the cilia are trafficked via vesicles, there is increasing interest in vesicle trafficking as it relates to cilia and basal bodies. This has been beautifully shown for the BBSome. Comprised of proteins associated with the ciliopathy BBS, this complex helps target vesicles to the cilia. Specifically, the BBSome is required for ciliary membrane biogenesis, and is targeted to cilia via Rabin8-mediated activation of Rab8 (Nachury et al. 2007). Interestingly, Rabin8 is localized to basal bodies, as is Rab11, which stimulates the Rabin8
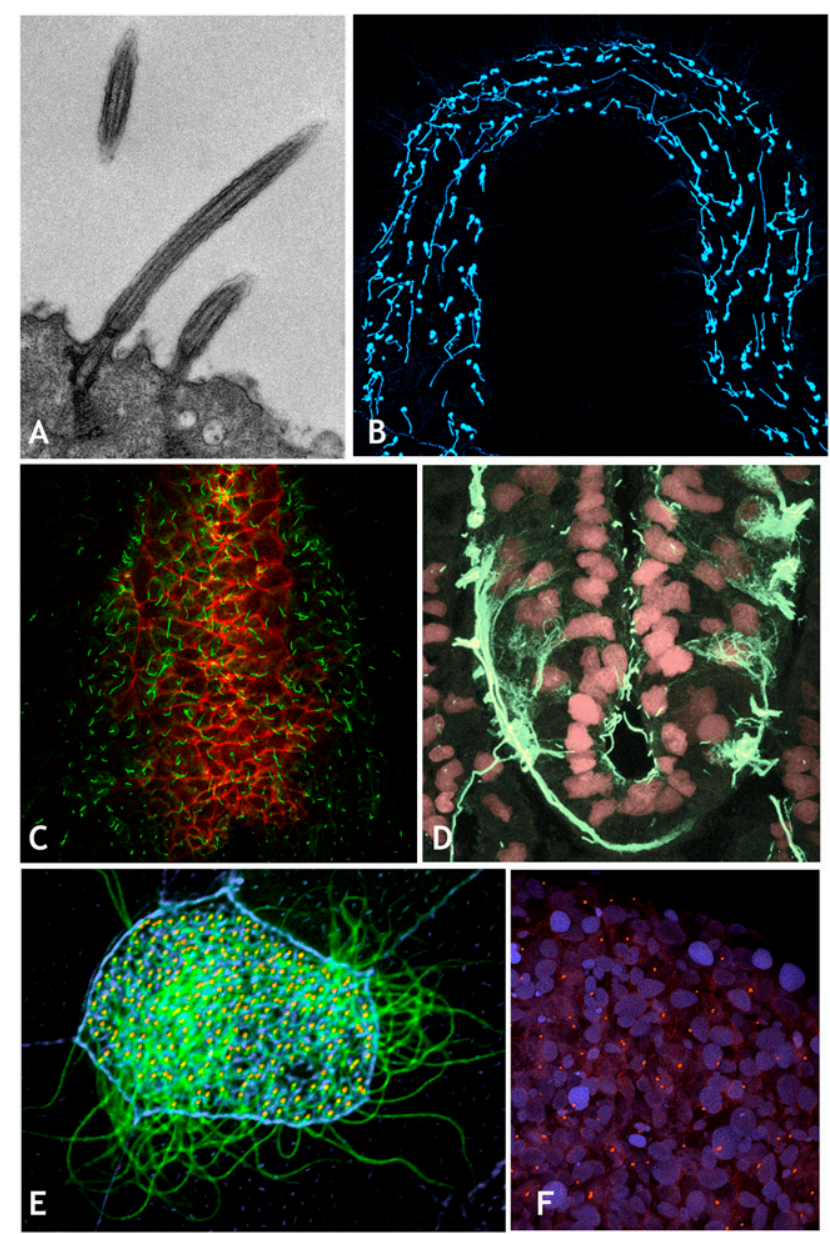

Figure 1. Cilia diversity. (A) Transmission electron microscopy of motile cilia; basal body-associated structures are evident, including the downward-pointing striated rootlets, thought to be platforms for vesicle docking. $(B)$ Cilia in a kidney tubule; defects in kidney cilia are associated with polycystic kidney disease. $(C)$ Motile monocilia in the early embryo generate fluid flow that is essential for normal left/right patterning. Patients with primary ciliary dyskinesia frequently display situs inversus. $(D)$ Cilia in the lumen of the neural tube. (The acetylated tubulin immunostaining also highlights axon bundles.) These neural tube cilia are essential for normal Hedgehogmediated patterning of the CNS. (E) A multiciliated cell. These cells beat directionally to move fluid in the airway, CNS, and oviducts. Defects in these cilia lead to respiratory problems and hydrocephalus. $(F)$ Primary cilia in developing endoderm. Primary cilia in various tissues appear to perform a wide range of sensory functions, and animals with defective cilia display defects in the lung, kidney, liver, and heart.

activation of Rab8 (Knodler et al. 2010). Finally, Ahi/Jbn is implicated in ciliogenesis via a role in targeting of Rab8 (Hsiao et al. 2009), although it should be noted that a separate study failed to find a role for Ahil/Jbn in ciliogenesis (Lancaster et al. 2009).

The BBSome is not the only important basal body/ vesicle interaction, however. Dvl, for example, localizes adjacent to the basal body and appears to mediate recruitment of sec8-positive vesicles (Park et al. 2008). Dvl 
influences both the planar orientation and assembly of motile cilia in multiciliated cells (Park et al. 2008; Mitchell et al. 2009; Hirota et al. 2010). In addition, it is possible that Dvl's presence near basal bodies is also related to canonical Wnt signaling and/or "post-docking" vesicle traffic, as a number of vesicle trafficking proteins have been linked to Wnt signaling via Dvl (Capelluto et al. 2002; Chen et al. 2003; Yu et al. 2007).

\section{Ciliary pores and gatekeepers}

Nuclear pores have been studied extensively and are well characterized for their ability to limit protein entry into the nucleus. Nuclear entry through a pore requires a specific amino acid sequence (the nuclear localization sequence) and is facilitated by binding to importin $\beta 2$. The binding of cargo to importin $\beta 2$ is in turn tightly regulated by the Ran GTPase. Ran-GTP, at low levels in the cytoplasm, allows the association of nuclear cargoes with importin B2, while high levels of Ran-GTP in the nucleus disrupt these associations (Harel and Forbes 2004).

Interestingly, GTP-bound Ran was also found recently at high levels in cilia, leading to the proposal that a homologous ciliary pore requiring a ciliary localization signal (CLS) and interaction with importin $\beta 2$ governs localization of proteins to cilia (Dishinger et al. 2010). High levels of Ran-GTP in the cilia would then disrupt the interaction between the CLS and importin $\beta 2$, thereby blocking exit. This model is supported by the finding that importin $\beta 1$ is also present in cilia, and that dominant-negative importin $\beta 1$ disrupts ciliogenesis (Fan et al. 2007).

How the Ran-mediated entry system interacts with other ciliary trafficking systems (such as IFT and BBS systems) (see below) has not yet been investigated. Indeed, while the importin system has been shown very nicely to govern entry of kinesin Kif17, it remains to be determined how pervasive this mechanism is for the many proteins that make up the ciliome (Dishinger et al. 2010). An additional candidate for trafficking by this system is the protein encoded by the CLPI splice variant of Crumbs3, as this protein is present in cilia, controls ciliogenesis, and also interacts with importin $\beta$ in a Ran-dependent manner (Fan et al. 2007).

This new link between nuclear pore machinery and ciliary trafficking may provide an entry point for additional studies exploring the mechanisms by which cilia or ciliary proteins impact Wnt signaling. For example, the Chibby protein is an antagonist of canonical Wnt signaling, acting in concert with importin $\alpha$ and 14-3-3 proteins to govern the nucleocytoplasmic shuttling of $\beta$-catenin (Li et al. 2008, 2010). It is therefore particularly intriguing that Chibby also localizes to the base of cilia in airway epithelial cells and MDCK2 cells (Voronina et al. 2009). One interpretation is that this represents another example of the shared mechanism regulating nuclear pore/ciliary pore trafficking.

In addition, a possible link between Chibby and PCP proteins comes from the finding that Chibby mutant mice display defects in ciliogenesis in multiciliated cells of the airway (Voronina et al. 2009). Indeed, these cilio- genesis defects stem from a failure of basal body docking, as is the case for ciliogenesis defects arising from manipulations of Dvl or Celsr proteins (Park et al. 2008; Voronina et al. 2009; Tissir et al. 2010). Finally, one of the 14-3-3 proteins that was found to bind Chibby is also implicated in ciliogenesis (Fan et al. 2004).

\section{Diffusion barriers}

Just as the importin $\beta$ results expose the gated community of soluble proteins in the ciliary compartment, other recent data demonstrate that ciliary membrane is likewise a highly exclusive piece of property. In addition to the BBSome/Rab8 system, which preferentially delivers membrane proteins to cilia, there is also a system in place to maintain a continuous partition between the ciliary membrane and the adjoining nonciliary plasma membrane.

Early insights into the mechanism of this partitioning came with the demonstration that Fapp2, an apical membrane targeting protein, is essential for ciliogenesis (Vieira et al. 2006). This study described a specialized zone of highly condensed lipids at the base of cilia that excludes apical, nonciliary proteins. Fapp2 is required for the partitioning of the more- and less-ordered lipids on the apical membrane (Vieira et al. 2006).

Similar membrane diffusion barriers are observed in a variety of cellular contexts, such as the cytokinetic furrow. In yeast, the septins are a major component of such diffusion barriers (for review, see Gladfelter et al. 2001), and they appear to play a similar role at the base of neuronal dendrites (Caudron and Barral 2009). There is now evidence that septins also act in the diffusion barriers at the base of cilia. Septins form rings at the base of both primary cilia in IMCD3 cells and in motile cilia in the Xenopus epidermis, and septins are essential for ciliogenesis in both cell types (Hu et al. 2010; Kim et al. 2010). Careful FRAP studies revealed that disruption of septins alters the diffusional mobility of several ciliary membrane proteins. Thus, septins appear to act as the physical diffusion barrier that gives cilia the distinct membrane composition and specific localization of various membrane receptors (Hu et al. 2010).

This role for septins in ciliogenesis has provided some measure of a unifying mechanism for the role of PCP proteins in ciliogenesis and polarized, collective cell movements. The PCP effector protein Fritz is essential for Drosophila wing hair polarity (Collier et al. 2005), and in Xenopus is required for both CE and ciliogenesis (Kim et al. 2010). Fritz is required to control septin localization during both ciliogenesis and CE (Kim et al. 2010).

Finally, another potential component of the ciliary diffusion barrier is Arl6 (BBS3), which, like septins, localizes to a ring-like structure at the base of the cilium (Wiens et al. 2010). Interestingly, overexpression of ARL6 causes ciliogenesis defects and an increased responsiveness to Wnt signaling (Wiens et al. 2010).

\section{IFT}

In addition to targeting of ciliary components to the basal body and modulating molecules that get into cilia, it is 
also possible that IFT molecules may preferentially carry specific cargos. This may occur at the level of protein sorting in the transition zone near the base of cilia, as has been suggested by results in the photoreceptors of Nphp1 mutant mice and in Chlamydomonas CEP290 mutants (Jiang et al. 2009; Craige et al. 2010). Additionally, while there is a typical rate of motion for IFT molecules, FRAP experiments of different ciliary components revealed that there are different rates of recovery after photobleaching, suggesting that different molecules are preferentially trafficked (Boehlke et al. 2010). In fact, Rab5 and Rab23 differentially modulate recovery of selective molecules, further suggesting that ciliary trafficking is a highly regulated process and not simply a matter of the most abundant proteins stochastically being transported faster (Boehlke et al. 2010). Other data suggest that specific adaptors link different subsets of ciliary proteins to the IFT complex. Tulp3, for example, controls the ciliary localization of g-protein-coupled receptors such as rhodopsin, but does not affect ciliary trafficking of Rab8a or Smoothened (Mukhopadhyay et al. 2010).

An intriguing combination of the idea of ciliary gatekeeping and preferential IFT stems from the results that CEP290 specifically localizes at the transition zone and is responsible for mediating the interaction between the axoneme and the ciliary membrane (Craige et al. 2010). In the absence of CEP290, there is a drastic alteration of the ciliary protein ensemble, and, in particular, there are modifications in the amount of various IFT components (Craige et al. 2010). These results suggest that the ciliary gatekeepers, in addition to sorting ciliary proteins, can also regulate the transport of these proteins by modulating the number of particular IFT molecules.

\section{Final thoughts}

The first evidence for cilia on vertebrate animals probably came from Steinbuch (1802, as described in Sharpey 1835, 1836), who reported fluid flow across the surface of tadpoles at the turn of the 19th century. The legendary biologist Purkyně and his student, Valentin (Valentin and Purkyně 1834, translated in Sharpey 1835), first described motile cilia in vertebrate airways and correctly conjectured that they might aid in the removal of mucus. Then, as now, cilia were a touchy subject, as Valentin and Purkyně (1834) somewhat indelicately pointed out that Steinbuch's result "does not altogether correspond with nature" (Steinbuch 1802; Valentin and Purkyně 1834, as translated in Sharpey 1835). Another 150 years would pass before the first reports of primary cilia would emerge. At that time, these widespread, nonmotile cilia were proposed to serve a sensory function (Munger 1958; Sorokin 1962), and now the widespread links between these primary cilia and cell-cell signaling in vertebrates are generating exciting, if contentious, new concepts in development and disease.

The variety of subtle Wnt defects seen in various cell types following manipulations of ciliary proteins are hard to ignore. The variability here may stem from the concerted efforts of ciliary pores, diffusion barriers, and differential IFT transport that tightly regulate ciliary com- position in different cell types, or, alternatively, it remains at least possible that the whole could be a complex illusion. Perhaps the links are not between cilia and Wnt signaling at all, but rather stem from the pleiotropic nature of the proteins under study. One thing is clear. Sharpey's thoughts from 1835 remain true today: Further investigations will be "rewarded by much curious and interesting discovery" (Sharpey 1835).

\section{Acknowledgments}

We thank Jeff Axelrod, Jeremy Nathans, Eszter Vladar, Diane Sepich, and Andrew Copp for critical reading, and Sara Peyrot, Jeremy O'Connell, and Michael Werner for images. We also note that the works of William Sharpey cited herein make for fascinating reading and can be obtained via Google Books. This work was supported by grants from the Parker B. Francis Foundation and the NIH/NIMGS to B.J.M.. and from the NIH/NIGMS, March of Dimes, and Burroughs Wellcome Fund to J.B.W. J.B.W. is an Early Career Scientist of the Howard Hughes Medical Institute.

\section{References}

Adler PN. 2002. Planar signaling and morphogenesis in Drosophila. Dev Cell 2: 525-535.

Adler PN, Zhu C, Stone D. 2004. Inturned localizes to the proximal side of wing cells under the instruction of upstream planar polarity proteins. Curr Biol 14: 2046-2051.

Ang SF, Zhao ZS, Lim L, Manser E. 2010. DAAM1 is a formin required for centrosome re-orientation during cell migration. PLOS ONE 5: e13064. doi: 10.1371/journal.pone.0013064.

Antic D, Stubbs JL, Suyama K, Kintner C, Scott MP, Axelrod JD. 2010. Planar cell polarity enables posterior localization of nodal cilia and left-right axis determination during mouse and Xenopus embryogenesis. PLOS ONE 5: e8999. doi: 10.1371/journal.pone.008999.

Baker K, Beales PL. 2009. Making sense of cilia in disease: The human ciliopathies. Am J Med Genet C Semin Med Genet 151C: $281-295$.

Bastock R, Strutt H, Strutt D. 2003. Strabismus is asymmetrically localised and binds to Prickle and Dishevelled during Drosophila planar polarity patterning. Development 130: 3007-3014.

Boehlke C, Bashkurov M, Buescher A, Krick T, John AK, Nitschke R, Walz G, Kuehn EW. 2010. Differential role of Rab proteins in ciliary trafficking: Rab23 regulates smoothened levels. J Cell Sci 123: 1460-1467.

Boisvieux-Ulrich E, Laine MC, Sandoz D. 1990. Cytochalasin D inhibits basal body migration and ciliary elongation in quail oviduct epithelium. Cell Tissue Res 259: 443-454.

Borovina A, Superina S, Voskas D, Ciruna B. 2010. Vangl2 directs the posterior tilting and asymmetric localization of motile primary cilia. Nat Cell Biol 12: 407-412.

Capelluto DG, Kutateladze TG, Habas R, Finkielstein CV, He X, Overduin M. 2002. The DIX domain targets dishevelled to actin stress fibres and vesicular membranes. Nature 419: 726-729.

Caspary T, Larkins CE, Anderson KV. 2007. The graded response to Sonic Hedgehog depends on cilia architecture. Dev Cell 12: $767-778$.

Caudron F, Barral Y. 2009. Septins and the lateral compartmentalization of eukaryotic membranes. Dev Cell 16: 493-506.

Chen W, ten Berge D, Brown J, Ahn S, Hu LA, Miller WE, Caron MG, Barak LS, Nusse R, Lefkowitz RJ. 2003. Dishevelled 2 recruits $\beta$-arrestin 2 to mediate Wnt5A-stimulated endocytosis of Frizzled 4. Science 301: 1391-1394. 
Colas JF, Schoenwolf GC. 2001. Towards a cellular and molecular understanding of neurulation. Dev Dyn 221: 117-145.

Collier S, Gubb D. 1997. Drosophila tissue polarity requires the cell-autonomous activity of the fuzzy gene, which encodes a novel transmembrane protein. Development 124: 40294037.

Collier S, Lee H, Burgess R, Adler P. 2005. The WD40 repeat protein fritz links cytoskeletal planar polarity to frizzled subcellular localization in the Drosophila epidermis. Genetics 169: 2035-2045.

Copp AJ, Greene ND, Murdoch JN. 2003. Dishevelled: Linking convergent extension with neural tube closure. Trends Neurosci 26: 453-455.

Corbit KC, Shyer AE, Dowdle WE, Gaulden J, Singla V, Chen MH, Chuang PT, Reiter JF. 2008. Kif3a constrains $\beta$-catenindependent Wnt signalling through dual ciliary and nonciliary mechanisms. Nat Cell Biol 10: 70-76.

Courbard JR, Djiane A, Wu J, Mlodzik M. 2009. The apical/ basal-polarity determinant Scribble cooperates with the PCP core factor Stbm/Vang and functions as one of its effectors. Dev Biol 333: 67-77.

Craige B, Tsao CC, Diener DR, Hou Y, Lechtreck KF, Rosenbaum JL, Witman GB. 2010. CEP290 tethers flagellar transition zone microtubules to the membrane and regulates flagellar protein content. J Cell Biol 190: 927-940.

Curtin JA, Quint E, Tsipouri V, Arkell RM, Cattanach B, Copp AJ, Henderson DJ, Spurr N, Stanier P, Fisher EM, et al. 2003. Mutation of Celsrl disrupts planar polarity of inner ear hair cells and causes severe neural tube defects in the mouse. Curr Biol 13: 1129-1133.

Dai D, Zhu H, Wlodarczyk B, Zhang L, Li L, Li AG, Finnell RH, Roop DR, Chen J. 2010. Fuz controls the morphogenesis and differentiation of hair follicles through the formation of primary cilia. J Invest Dermatol doi: 10.1038/jid.2010.306.

Das G, Jenny A, Klein TJ, Eaton S, Mlodzik M. 2004. Diego interacts with Prickle and Strabismus/Van Gogh to localize planar cell polarity complexes. Development 131: 44674476.

da Silva SM, Vincent JP. 2007. Oriented cell divisions in the extending germband of Drosophila. Development 134: 30493054.

Deans MR, Antic D, Suyama K, Scott MP, Axelrod JD, Goodrich LV. 2007. Asymmetric distribution of prickle-like 2 reveals an early underlying polarization of vestibular sensory epithelia in the inner ear. I Neurosci 27: 3139-3147.

Devenport D, Fuchs E. 2008. Planar polarization in embryonic epidermis orchestrates global asymmetric morphogenesis of hair follicles. Nat Cell Biol 10: 1257-1268.

Dishinger JF, Kee HL, Jenkins PM, Fan S, Hurd TW, Hammond JW, Truong YN, Margolis B, Martens JR, Verhey KJ. 2010. Ciliary entry of the kinesin-2 motor KIF17 is regulated by importin- $\beta 2$ and RanGTP. Nat Cell Biol 12: 703-710.

Dobell C. 1958. Antony van Leeuwenhoek and his little animals. Russell and Russell, New York.

Eggenschwiler JT, Anderson KV. 2007. Cilia and developmental signaling. Annu Rev Cell Dev Biol 23: 345-373.

Fan S, Hurd TW, Liu CJ, Straight SW, Weimbs T, Hurd EA, Domino SE, Margolis B. 2004. Polarity proteins control ciliogenesis via kinesin motor interactions. Curr Biol 14: 1451-1461.

Fan S, Fogg V, Wang Q, Chen XW, Liu CJ, Margolis B. 2007. A novel Crumbs3 isoform regulates cell division and ciliogenesis via importin $\beta$ interactions. J Cell Biol 178: 387-398.

Feiguin F, Hannus M, Mlodzik M, Eaton S. 2001. The ankyrin repeat protein Diego mediates Frizzled-dependent planar polarization. Dev Cell 1: 93-101.
Ferrante MI, Romio L, Castro S, Collins JE, Goulding DA, Stemple DL, Woolf AS, Wilson SW. 2009. Convergent extension movements and ciliary function are mediated by ofd1, a zebrafish orthologue of the human oral-facial-digital type 1 syndrome gene. Hum Mol Genet 18: 289-303.

Finetti F, Paccani SR, Riparbelli MG, Giacomello E, Perinetti G, Pazour GJ, Rosenbaum JL, Baldari CT. 2009. Intraflagellar transport is required for polarized recycling of the TCR/CD3 complex to the immune synapse. Nat Cell Biol 11: 13321339 .

Gerdes JM, Liu Y, Zaghloul NA, Leitch CC, Lawson SS, Kato M, Beachy PA, Beales PL, DeMartino GN, Fisher S, et al. 2007. Disruption of the basal body compromises proteasomal function and perturbs intracellular Wnt response. Nat Genet 39: $1350-1360$.

Gladfelter AS, Pringle JR, Lew DJ. 2001. The septin cortex at the yeast mother-bud neck. Curr Opin Microbiol 4: 681-689.

Goetz SC, Anderson KV. 2010. The primary cilium: A signalling centre during vertebrate development. Nat Rev Genet 11: 331-344.

Gomes ER, Jani S, Gundersen GG. 2005. Nuclear movement regulated by Cdc42, MRCK, myosin, and actin flow establishes MTOC polarization in migrating cells. Cell 121: 451463.

Gray RS, Abitua PB, Wlodarczyk BI, Szabo-Rogers HL, Blanchard O, Lee I, Weiss GS, Liu KJ, Marcotte EM, Wallingford JB, et al. 2009. The planar cell polarity effector Fuz is essential for targeted membrane trafficking, ciliogenesis and mouse embryonic development. Nat Cell Biol 11: 1225-1232.

Green JB, Davidson LA. 2007. Convergent extension and the hexahedral cell. Nat Cell Biol 9: 1010-1015.

Guirao B, Meunier A, Mortaud S, Aguilar A, Corsi JM, Strehl L, Hirota Y, Desoeuvre A, Boutin C, Han YG, et al. 2010. Coupling between hydrodynamic forces and planar cell polarity orients mammalian motile cilia. Nat Cell Biol 12: 341-350.

Guo N, Hawkins C, Nathans J. 2004. Frizzled6 controls hair patterning in mice. Proc Natl Acad Sci 101: 9277-9281.

Habas R, Kato Y, He X. 2001. Wnt/Frizzled activation of Rho regulates vertebrate gastrulation and requires a novel Formin homology protein Daam1. Cell 107: 843-854.

Habas R, Dawid IB, He X. 2003. Coactivation of Rac and Rho by Wnt/Frizzled signaling is required for vertebrate gastrulation. Genes Dev 17: 295-309.

Hamblet NS, Lijam N, Ruiz-Lozano P, Wang J, Yang Y, Luo Z, Mei L, Chien KR, Sussman DI, Wynshaw-Boris A. 2002. Dishevelled 2 is essential for cardiac outflow tract development, somite segmentation and neural tube closure. Development 129: 5827-5838.

Han YG, Kim HJ, Dlugosz AA, Ellison DW, Gilbertson RJ, Alvarez-Buylla A. 2009. Dual and opposing roles of primary cilia in medulloblastoma development. Nat Med 15: 10621065.

Harel A, Forbes DJ. 2004. Importin $\beta$ : Conducting a much larger cellular symphony. Mol Cell 16: 319-330.

Hashimoto M, Shinohara K, Wang J, Ikeuchi S, Yoshiba S, Meno C, Nonaka S, Takada S, Hatta K, Wynshaw-Boris A, et al. 2010. Planar polarization of node cells determines the rotational axis of node cilia. Nat Cell Biol 12: 170-176.

Heisenberg CP, Tada M, Rauch GJ, Saude L, Concha ML, Geisler R, Stemple DL, Smith JC, Wilson SW. 2000. Silberblick/ Wnt11 mediates convergent extension movements during zebrafish gastrulation. Nature 405: 76-81.

Heydeck W, Zeng H, Liu A. 2009. Planar cell polarity effector gene Fuzzy regulates cilia formation and Hedgehog signal transduction in mouse. Dev Dyn 238: 3035-3042. 
Hirota Y, Meunier A, Huang S, Shimozawa T, Yamada O, Kida YS, Inoue M, Ito T, Kato H, Sakaguchi M, et al. 2010. Planar polarity of multiciliated ependymal cells involves the anterior migration of basal bodies regulated by non-muscle myosin II. Development 137: 3037-3046.

Hsiao YC, Tong ZJ, Westfall JE, Ault JG, Page-McCaw PS, Ferland RJ. 2009. Ahil, whose human ortholog is mutated in Joubert syndrome, is required for Rab8a localization, ciliogenesis and vesicle trafficking. Hum Mol Genet 18: 3926-3941.

Hu Q, Milenkovic L, Jin H, Scott MP, Nachury MV, Spiliotis ET, Nelson WJ. 2010. A septin diffusion barrier at the base of the primary cilium maintains ciliary membrane protein distribution. Science 329: 436-439.

Huang P, Schier AF. 2009. Dampened Hedgehog signaling but normal Wnt signaling in zebrafish without cilia. Development 136: 3089-3098.

Huang T, You Y, Spoor MS, Richer EJ, Kudva VV, Paige RC, Seiler MP, Liebler JM, Zabner J, Plopper CG, et al. 2003. Foxj1 is required for apical localization of ezrin in airway epithelial cells. J Cell Sci 116: 4935-4945.

Huangfu D, Anderson KV. 2005. Cilia and Hedgehog responsiveness in the mouse. Proc Natl Acad Sci 102: 11325-11330.

Huangfu D, Liu A, Rakeman AS, Murcia NS, Niswander L, Anderson KV. 2003. Hedgehog signalling in the mouse requires intraflagellar transport proteins. Nature 426: 83-87.

Jiang ST, Chiou YY, Wang E, Chien YL, Ho HH, Tsai FJ, Lin CY, Tsai SP, Li H. 2009. Essential role of nephrocystin in photoreceptor intraflagellar transport in mouse. Hum Mol Genet 18: 1566-1577.

Jonassen JA, San Agustin J, Follit JA, Pazour GJ. 2008. Deletion of IFT20 in the mouse kidney causes misorientation of the mitotic spindle and cystic kidney disease. I Cell Biol 183: 377-384.

Jones C, Roper VC, Foucher I, Qian D, Banizs B, Petit C, Yoder BK, Chen P. 2008. Ciliary proteins link basal body polarization to planar cell polarity regulation. Nat Genet 40: 69-77.

Keller R. 2002. Shaping the vertebrate body plan by polarized embryonic cell movements. Science 298: 1950-1954.

Kibar Z, Vogan KJ, Groulx N, Justice MJ, Underhill DA, Gros P. 2001. Ltap, a mammalian homolog of Drosophila Strabismus/Van Gogh, is altered in the mouse neural tube mutant Loop-tail. Nat Genet 28: 251-255.

Kim SK, Shindo A, Park TJ, Oh EC, Ghosh S, Gray RS, Lewis RA, Johnson CA, Attie-Bittach T, Katsanis N, et al. 2010. Planar cell polarity acts through septins to control collective cell movement and ciliogenesis. Science 329: 1337-1340.

Kishimoto N, Cao Y, Park A, Sun Z. 2008. Cystic kidney gene seahorse regulates cilia-mediated processes and Wnt pathways. Dev Cell 14: 954-961.

Knodler A, Feng S, Zhang J, Zhang X, Das A, Peranen J, Guo W. 2010. Coordination of Rab8 and Rab11 in primary ciliogenesis. Proc Natl Acad Sci 107: 6346-6351.

Kupfer A, Louvard D, Singer SJ. 1982. Polarization of the Golgi apparatus and the microtubule-organizing center in cultured fibroblasts at the edge of an experimental wound. Proc Natl Acad Sci 79: 2603-2607.

Lancaster MA, Louie CM, Silhavy JL, Sintasath L, Decambre M, Nigam SK, Willert K, Gleeson JG. 2009. Impaired Wnt$\beta$-catenin signaling disrupts adult renal homeostasis and leads to cystic kidney ciliopathy. Nat Med 15: 1046-1054.

Lee H, Adler PN. 2002. The function of the frizzled pathway in the Drosophila wing is dependent on inturned and fuzzy. Genetics 160: 1535-1547.

Lee E, Salic A, Kruger R, Heinrich R, Kirschner MW. 2003. The roles of APC and Axin derived from experimental and theoretical analysis of the Wnt pathway. PLoS Biol 1: e10. doi: 10.1371/journal.pbio.0000010.

Leitch CC, Zaghloul NA, Davis EE, Stoetzel C, Diaz-Font A, Rix S, Alfadhel M, Lewis RA, Eyaid W, Banin E, et al. 2008. Hypomorphic mutations in syndromic encephalocele genes are associated with Bardet-Biedl syndrome. Nat Genet 40: 443-448.

Li FQ, Mofunanya A, Harris K, Takemaru K. 2008. Chibby cooperates with 14-3-3 to regulate $\beta$-catenin subcellular distribution and signaling activity. J Cell Biol 181: 1141-1154.

Li FQ, Mofunanya A, Fischer V, Hall J, Takemaru K. 2010. Nuclear-cytoplasmic shuttling of Chibby controls $\beta$-catenin signaling. Mol Biol Cell 21: 311-322.

Liu A, Wang B, Niswander LA. 2005. Mouse intraflagellar transport proteins regulate both the activator and repressor functions of Gli transcription factors. Development 132: 3103-3111.

Louie CM, Caridi G, Lopes VS, Brancati F, Kispert A, Lancaster MA, Schlossman AM, Otto EA, Leitges M, Grone HJ, et al. 2010. AHIl is required for photoreceptor outer segment development and is a modifier for retinal degeneration in nephronophthisis. Nat Genet 42: 175-180.

Marlow F, Topczewski J, Sepich D, Solnica-Krezel L. 2002. Zebrafish Rho kinase 2 acts downstream of Wnt11 to mediate cell polarity and effective convergence and extension movements. Curr Biol 12: 876-884.

Marshall WF. 2007. What is the function of centrioles? J Cell Biochem 100: 916-922.

May-Simera HL, Kai M, Hernandez V, Osborn DP, Tada M, Beales PL. 2010. Bbs8, together with the planar cell polarity protein Vang12, is required to establish left-right asymmetry in zebrafish. Dev Biol 345: 215-225.

McDermott KM, Liu BY, Tlsty TD, Pazour GJ. 2010. Primary cilia regulate branching morphogenesis during mammary gland development. Curr Biol 20: 731-737.

McNeill H. 2010. Planar cell polarity: Keeping hairs straight is not so simple. Cold Spring Harb Perspect Biol 2: a003376. doi: 10.1101/cshperspect.a003376.

Mirzadeh Z, Han YG, Soriano-Navarro M, Garcia-Verdugo JM, Alvarez-Buylla A. 2010. Cilia organize ependymal planar polarity. J Neurosci 30: 2600-2610.

Mitchell B, Stubbs JL, Huisman F, Taborek P, Yu C, Kintner C. 2009. The PCP pathway instructs the planar orientation of ciliated cells in the Xenopus larval skin. Curr Biol 19: 924 929.

Montcouquiol M, Rachel RA, Lanford PJ, Copeland NG, Jenkins NA, Kelley MW. 2003. Identification of Vangl2 and Scrb1 as planar polarity genes in mammals. Nature 423: 173-177.

Mukhopadhyay S, Wen X, Chih B, Nelson CD, Lane WS, Scales SJ, Jackson PK. 2010. TULP3 bridges the IFT-A complex and membrane phosphoinositides to promote trafficking of $\mathrm{G}$ protein-coupled receptors into primary cilia. Genes Dev 24: $2180-2193$.

Munger BL. 1958. A light and electron microscopic study of cellular differentiation in the pancreatic islets of the mouse. Am I Anat 103: 275-311.

Murdoch JN, Copp AJ. 2010. The relationship between sonic Hedgehog signaling, cilia, and neural tube defects. Birth Defects Res A Clin Mol Teratol 88: 633-652.

Murdoch JN, Henderson DJ, Doudney K, Gaston-Massuet C, Phillips HM, Paternotte C, Arkell R, Stanier P, Copp AJ. 2003. Disruption of scribble (Scrb1) causes severe neural tube defects in the circletail mouse. Hum Mol Genet 12: 87-98.

Nachury MV, Loktev AV, Zhang Q, Westlake CJ, Peranen J, Merdes A, Slusarski DC, Scheller RH, Bazan JF, Sheffield VC, et al. 2007. A core complex of BBS proteins cooperates with 
the GTPase Rab8 to promote ciliary membrane biogenesis. Cell 129: 1201-1213.

Nigg EA. 2007. Centrosome duplication: Of rules and licenses. Trends Cell Biol 17: 215-221.

Ocbina PJ, Tuson M, Anderson KV. 2009. Primary cilia are not required for normal canonical Wnt signaling in the mouse embryo. PLoS ONE 4: e6839. doi: 10.1371/journal.pone. 0006839.

Oishi I, Kawakami Y, Raya A, Callol-Massot C, Izpisua Belmonte JC. 2006. Regulation of primary cilia formation and left-right patterning in zebrafish by a noncanonical Wnt signaling mediator, duboraya. Nat Genet 38: 1316-1322.

Oteiza P, Koppen M, Krieg M, Pulgar E, Farias C, Melo C, Preibisch S, Muller D, Tada M, Hartel S, et al. 2010. Planar cell polarity signalling regulates cell adhesion properties in progenitors of the zebrafish laterality organ. Development 137: 3459-3468.

Otto EA, Schermer B, Obara T, O'Toole JF, Hiller KS, Mueller AM, Ruf RG, Hoefele J, Beekmann F, Landau D, et al. 2003. Mutations in INVS encoding inversin cause nephronophthisis type 2, linking renal cystic disease to the function of primary cilia and left-right axis determination. Nat Genet 34: 413-420.

Pan J, You Y, Huang T, Brody SL. 2007. RhoA-mediated apical actin enrichment is required for ciliogenesis and promoted by Foxj1. J Cell Sci 120: 1868-1876.

Park WJ, Liu J, Sharp EJ, Adler PN. 1996. The Drosophila tissue polarity gene inturned acts cell autonomously and encodes a novel protein. Development 122: 961-969.

Park TJ, Haigo SL, Wallingford JB. 2006. Ciliogenesis defects in embryos lacking inturned or fuzzy function are associated with failure of planar cell polarity and Hedgehog signaling. Nat Genet 38: 303-311.

Park TJ, Mitchell BJ, Abitua PB, Kintner C, Wallingford JB. 2008. Dishevelled controls apical docking and planar polarization of basal bodies in ciliated epithelial cells. Nat Genet 40: $871-$ 879.

Purkyně J, Valentin G. 1834. Discovery of continual vibratory motions produced by cilia as a general phenomenon in reptiles, birds, and mammiferous animals. Arch Anat Physiol wiss Med (Müller) 5: 391-400.

Rogers KK, Wilson PD, Snyder RW, Zhang X, Guo W, Burrow CR, Lipschutz JH. 2004. The exocyst localizes to the primary cilium in MDCK cells. Biochem Biophys Res Commun 319: 138-143.

Ross AJ, May-Simera H, Eichers ER, Kai M, Hill J, Jagger DJ, Leitch CC, Chapple JP, Munro PM, Fisher S, et al. 2005. Disruption of Bardet-Biedl syndrome ciliary proteins perturbs planar cell polarity in vertebrates. Nat Genet 37: 11351140.

Satir P. 1995. Landmarks in cilia research from Leeuwenhoek to us. Cell Motil Cytoskeleton 32: 90-94.

Schlessinger K, McManus EJ, Hall A. 2007. Cdc42 and noncanonical Wnt signal transduction pathways cooperate to promote cell polarity. J Cell Biol 178: 355-361.

Schneider L, Clement CA, Teilmann SC, Pazour GJ, Hoffmann EK, Satir P, Christensen ST. 2005. PDGFR $\alpha \alpha$ signaling is regulated through the primary cilium in fibroblasts. Curr Biol 15: 1861-1866.

Shah AS, Ben-Shahar Y, Moninger TO, Kline JN, Welsh MJ. 2009. Motile cilia of human airway epithelia are chemosensory. Science 325: 1131-1134.

Sharpey W. 1835. Account of the discovery by purkinje and valentin of ciliary motions in reptiles and warm blooded animals. In Edinburgh new philosophical journal (ed. R Jameson), pp. 114-128. Neill and Company, Edinburgh.
Sharpey W. 1836. Cilia. In The cyclopœedia of anatomy and physiology (ed. RB Todd), pp. 606-638. Sherwood, Gilbert, and Piper, London.

Shih J, Keller R. 1992. Cell motility driving mediolateral intercalation in explants of Xenopus laevis. Development 116: 901-914.

Shindo A, Yamamoto TS, Ueno N. 2008. Coordination of cell polarity during Xenopus gastrulation. PLoS One 3: e1600. doi: 10.1371/journal.pone.0001600.

Simons M, Gloy J, Ganner A, Bullerkotte A, Bashkurov M, Kronig C, Schermer B, Benzing T, Cabello OA, Jenny A, et al. 2005. Inversin, the gene product mutated in nephronophthisis type II, functions as a molecular switch between Wnt signaling pathways. Nat Genet 37: 537-543.

Singla V, Romaguera-Ros M, Garcia-Verdugo JM, Reiter JF. 2010. Ofd1, a human disease gene, regulates the length and distal structure of centrioles. Dev Cell 18: 410-424.

Sokol SY. 1996. Analysis of Dishevelled signalling pathways during Xenopus development. Curr Biol 6: 1456-1467.

Song H, Hu J, Chen W, Elliott G, Andre P, Gao B, Yang Y. 2010. Planar cell polarity breaks bilateral symmetry by controlling ciliary positioning. Nature 466: 378-382.

Sorokin S. 1962. Centrioles and the formation of rudimentary cilia by fibroblasts and smooth muscle cells. I Cell Biol 15: 363-377.

Sorokin SP. 1968. Reconstructions of centriole formation and ciliogenesis in mammalian lungs. J Cell Sci 3: 207-230.

Steinbuch JG. 1802. Analecten neuer Beobachtungen und Untersuchungen fur die Naturkunde. Furth.

Strutt DI. 2002. The asymmetric subcellular localisation of components of the planar polarity pathway. Semin Cell Dev Biol 13: 225-231.

Strutt D, Warrington SJ. 2008. Planar polarity genes in the Drosophila wing regulate the localisation of the FH3-domain protein Multiple Wing Hairs to control the site of hair production. Development 135: 3103-3111.

Tada M, Smith JC. 2000. Xwnt11 is a target of Xenopus Brachyury: Regulation of gastrulation movements via Dishevelled, but not through the canonical Wnt pathway. Development 127: 2227-2238.

Takemaru K, Yamaguchi S, Lee YS, Zhang Y, Carthew RW, Moon RT. 2003. Chibby, a nuclear $\beta$-catenin-associated antagonist of the Wnt/Wingless pathway. Nature 422: 905-909.

Tissir F, Qu Y, Montcouquiol M, Zhou L, Komatsu K, Shi D, Fujimori T, Labeau J, Tyteca D, Courtoy P, et al. 2010. Lack of cadherins Celsr2 and Celsr3 impairs ependymal ciliogenesis, leading to fatal hydrocephalus. Nat Neurosci 13: 700-707.

Tree DR, Shulman JM, Rousset R, Scott MP, Gubb D, Axelrod JD. 2002. Prickle mediates feedback amplification to generate asymmetric planar cell polarity signaling. Cell 109: 371381.

Valente EM, Logan CV, Mougou-Zerelli S, Lee JH, Silhavy JL, Brancati F, Iannicelli M, Travaglini L, Romani S, Illi B, et al. 2010. Mutations in TMEM216 perturb ciliogenesis and cause Joubert, Meckel and related syndromes. Nat Genet 42: 619625.

van Amerongen R, Nusse R. 2009. Towards an integrated view of Wnt signaling in development. Development 136: 32053214.

Vieira OV, Gaus K, Verkade P, Fullekrug J, Vaz WL, Simons K. 2006. FAPP2, cilium formation, and compartmentalization of the apical membrane in polarized Madin-Darby canine kidney (MDCK) cells. Proc Natl Acad Sci 103: 18556-18561.

Vladar EK, Antic D, Axelrod JD. 2009. Planar cell polarity signaling: The developing cell's compass. Cold Spring Harb Perspect Biol 1: a002964. doi: 10.1101/cshperspect.a002964. 
Voronina VA, Takemaru K, Treuting P, Love D, Grubb BR, Hajiar AM, Adams A, Li FQ, Moon RT. 2009. Inactivation of Chibby affects function of motile airway cilia. J Cell Biol 185: 225-233.

Wallingford JB. 2006. Planar cell polarity, ciliogenesis and neural tube defects. Hum Mol Genet 15: R227-R234. doi: 10.1093/ $\mathrm{hmg} / \mathrm{ddl} 216$.

Wallingford JB. 2010. Planar cell polarity signaling, cilia and polarized ciliary beating. Curr Opin Cell Biol 22: 597-604.

Wallingford JB, Harland RM. 2002. Neural tube closure requires Dishevelled-dependent convergent extension of the midline. Development 129: 5815-5825.

Wallingford JB, Rowning BA, Vogeli KM, Rothbacher U, Fraser SE, Harland RM. 2000. Dishevelled controls cell polarity during Xenopus gastrulation. Nature 405: 81-85.

Wang J, Hamblet NS, Mark S, Dickinson ME, Brinkman BC, Segil N, Fraser SE, Chen P, Wallingford JB, Wynshaw-Boris A. 2006. Dishevelled genes mediate a conserved mammalian PCP pathway to regulate convergent extension during neurulation. Development 133: 1767-1778.

Wang Y, Guo N, Nathans J. 2006. The role of Frizzled3 and Frizzled6 in neural tube closure and in the planar polarity of inner-ear sensory hair cells. J Neurosci 26: 2147-2156.

Watanabe D, Saijoh Y, Nonaka S, Sasaki G, Ikawa Y, Yokoyama T, Hamada H. 2003. The left-right determinant Inversin is a component of node monocilia and other 9+0 cilia. Development 130: 1725-1734.

Westfall JE, Hoyt C, Liu Q, Hsiao YC, Pierce EA, Page-McCaw PS, Ferland RJ. 2010. Retinal degeneration and failure of photoreceptor outer segment formation in mice with targeted deletion of the Joubert syndrome gene, Ahil. I Neurosci 30: 8759-8768.

Wiens CJ, Tong Y, Esmail MA, Oh E, Gerdes JM, Wang J, Tempel W, Rattner JB, Katsanis N, Park HW, et al. 2010. Bardet-Biedl syndrome-associated small GTPase ARL6 (BBS3) functions at or near the ciliary gate and modulates Wnt signaling. I Biol Chem 285: 16218-16230.

Willemarck N, Rysman E, Brusselmans K, Van Imschoot G, Vanderhoydonc F, Moerloose K, Lerut E, Verhoeven G, Van Roy FM, Vleminckx K, et al. 2010. Aberrant activation of fatty acid synthesis suppresses primary cilium formation and distorts tissue development. Cancer Res. doi: 10.1158/00085472.CAN-10-2524.

Wu J, Klein TJ, Mlodzik M. 2004. Subcellular localization of frizzled receptors, mediated by their cytoplasmic tails, regulates signaling pathway specificity. PLOS Biol 2: e158. doi: 10.1371/journal.pbio.0020158.

Ybot-Gonzalez P, Savery D, Gerrelli D, Signore M, Mitchell CE, Faux CH, Greene ND, Copp AJ. 2007. Convergent extension, planar-cell-polarity signalling and initiation of mouse neural tube closure. Development 134: 789-799.

Yu A, Rual JF, Tamai K, Harada Y, Vidal M, He X, Kirchhausen T. 2007. Association of Dishevelled with the clathrin AP-2 adaptor is required for Frizzled endocytosis and planar cell polarity signaling. Dev Cell 12: 129-141.

Yun UJ, Kim SY, Liu J, Adler PN, Bae E, Kim J, Park WJ. 1999. The inturned protein of Drosophila melanogaster is a cytoplasmic protein located at the cell periphery in wing cells. Dev Genet 25: 297-305.

Zallen JA, Wieschaus E. 2004. Patterned gene expression directs bipolar planar polarity in Drosophila. Dev Cell 6: 343-355.

Zeng H, Hoover AN, Liu A. 2010. PCP effector gene Inturned is an important regulator of cilia formation and embryonic development in mammals. Dev Biol 339: 418-428.

Zuo X, Guo W, Lipschutz JH. 2009. The exocyst protein Sec10 is necessary for primary ciliogenesis and cystogenesis in vitro. Mol Biol Cell 20: 2522-2529. 


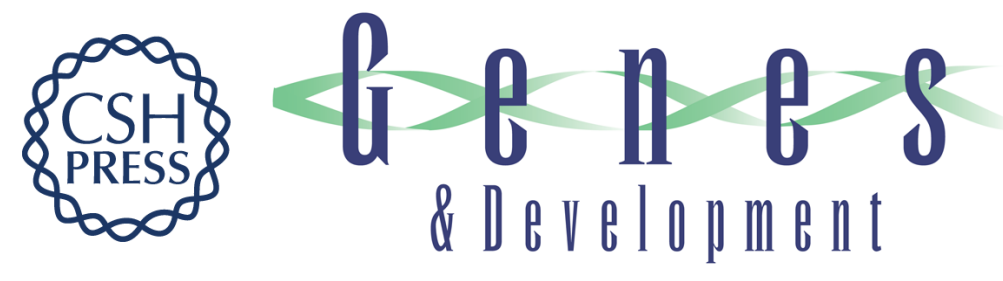

\section{Strange as it may seem: the many links between Wnt signaling, planar cell polarity, and cilia}

John B. Wallingford and Brian Mitchell

Genes Dev. 2011, 25:

Access the most recent version at doi:10.1101/gad.2008011

$\begin{array}{ll}\text { References } & \text { This article cites } 136 \text { articles, } 48 \text { of which can be accessed free at: } \\ \text { http://genesdev.cshlp.org/content/25/3/201.full.html\#ref-list-1 }\end{array}$

License Freely available online through the Genes \& Development Open Access option.

Email Alerting Receive free email alerts when new articles cite this article - sign up in the box at the top Service right corner of the article or click here.

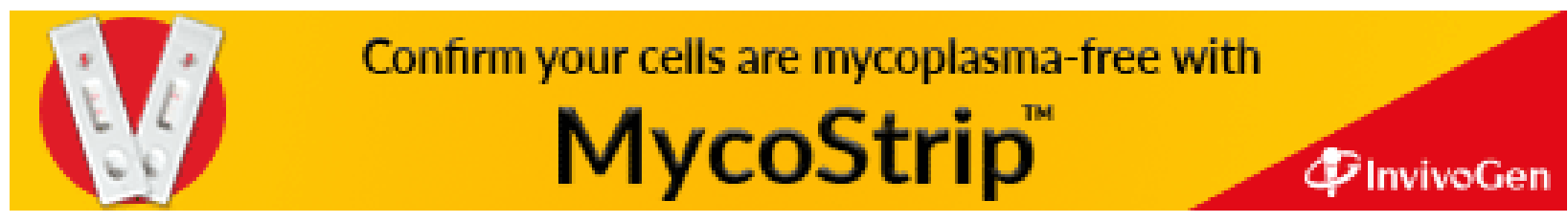

